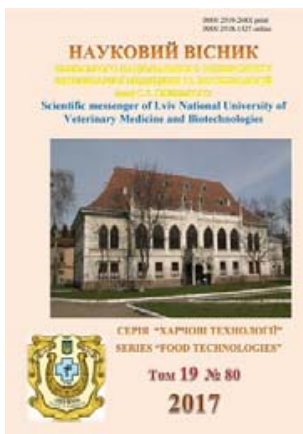

Науковий вісник Львівського національного університету ветеринарної медицини та біотехнологій імені С.3. Гжицького

Scientific Messenger of Lviv National University of Veterinary Medicine and Biotechnologies

doi:10.15421/nvlvet8004

ISSN 2519-268X print

ISSN 2518-1327 online

http://nvlvet.com.ua/

УДК 621.798.18:637.14

\title{
Вплив молока та сироватки на властивості їстівної плівки і покриття
}

\author{
О.С. Шульга, О.П. Перепелиця, С.І. Шульга \\ shulgaos@ukr.net, victanh@ukr.net,shulgasi2015@gmail.com \\ Національний університет харчових технологій, \\ вул. Володимирська, 68, м. Київ, 01601, Україна
}

\begin{abstract}
В статті наведено результати дослідження зміни властивостей їстівних плівок, виготовлених з крохмалю, желатину, полівінілового спирту як плівкоутворювачів, карбаміду як пластифікатора, лляної олії- гідрофобної складової та води або молока, або сироватки як розчинників. Авторами вперше запропоновано до складу їстівної плівки та покриття ввести молоко або сироватку як розчинник. На сьогодні в літературі наводяться дані щзодо застосування білків молока і сироват$\kappa и$, а також їх ізолятів як плівкоутворювачів. За допомогою комплексного органолептичного показника наведена доцільність заміни розчинника води на молоко та сироватку, оскільки вони не змінюють смак, запах, стан поверхні, колір та прозорість їстівної плівки та покриття. Крім того, молоко та сироватка збільцують харчову иінність їстівних плівок та покриттів, зокрема за такими складовими, як білок та кальцій. ІЧ-дослідження плівок показало, щчо розчинники впливають на характер, форму, смуги валентних коливань vОН-груп крохмалю. В ІЧ-спектрах на воді ия смуга більш вузька та інтен-

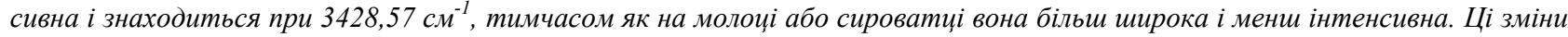
пов'язані з кількістю водневих зв'язків гідроксильної групи крохмалю зі складовими молока та сироватки. При використанні полівінілового спирту смуга vОН змішується в ділянку більш слабких коливань та знаходиться при 3400,56 см $^{-1}$, що обумовлено додатковими водневими зв'язками полівінілового спирту. Термогравіметричний аналіз показав, що молоко і сироватка сприяють більш міцному утриманню води за рахунок водневих зв'язків їх складових, щя збільшує температуру випаровування вологи та підтримує вологість системи впродовж терміну зберігання виробів. Показник паропроникності їстівних плівок, виготовлених на молоці та сироватиі, зменшується стосовно плівок, виготовлених на воді, щьо дозволяє рекомендувати молоко і сироватку як розчинник для виготовлення плівок з метою збільшення їх бар'єрних властивостей $i$, як наслідок, ие дозволить збільшити ефективність їстівної плівки як засобу збереження свіжості харчових продуктів.

Ключові слова: їстівні плівки та покриття, молоко, сироватка, полівініловий спирт, желатин, крохмаль картопляний, ІЧ-спектроскопія, термогравіметрія, термоліз, паропроникність.
\end{abstract}

\section{Влияние молока и сыворотки на свойства съедобных пленок и покрытий}

\author{
О.С. Шульга, А.П. Перепелица, С.И. Шульга \\ shulgaos@ukr.net, victanh@ukr.net,shulgasi2015@gmail.com \\ Национальный университет пищевых технологий, \\ ул. Владимирская, 68, г. Киев, 01601, Украина
}

\begin{abstract}
В статье приведены результаты исследования изменения свойств съедобных пленок, изготовленных из крахмала, желатина, поливинилового спирта в качестве пленкообразователей, карбамида в качестве пластификатора, льняного маслагидрофобной составляющей и воды или молока, или сыворотки как растворителей. Авторами впервые предложено в состав съедобной пленки и покрытия ввести молоко или сыворотку в качестве растворителя. Сегодня в литературе приводятся данные по применению белков молока и сыворотки, а также их изолятов в качестве пленкообразователей. С помощью комплексного органолептического показателя приведена иелесообразность замены растворителя воды на молоко и сыворотку, поскольку они не меняют вкус, запах, состояние поверхности, ивет и прозрачность съедобной пленки и покрытия. Кроме того, молоко и сыворотка увеличивают пищевую ценность съедобных пленок и покрытий, в частности по таким составляющим, как белок и кальций. ИК-исследования пленок показало, что растворители влияют на характер,
\end{abstract}

Citation:

Shulga, O.S., Perepelytsya, A.P., Shulga, S.I. (2017). Effect of milk and whey on properties of edible films and coatings. Scientific Messenger LNUVMB, 19(80), 18-24. 
форму полосы валентных колебаний vОН-групп крахмала. В ИК-спектрах на воде эта полоса более узкая и интенсивная и находится при 3428,57 см $^{-1}$, тогда как на молоке или сыворотке она более иирокая и менее интенсивная. Эти изменения связаны с количеством водородных связей гидроксильной группь крахмала с составляюшими молока и сыворотки. При использовании поливинилового спирта полоса vОН смещчается в область более слабых колебаний и находится при 3400,56 $\mathrm{cm}^{-1}$, что обусловлено образованием дополнительных водородных связей поливинилового спирта. Термогравиметрический анализ показал, что молоко и сыворотка способствуют более прочному удержанию воды за счет водородных связей их составляюших, увеличивают температуру испарения влаги и поддерживают влажность системь в течение срока хранения изделий. Показатель паропроницаемости съедобных пленок изготовленных на молоке и сыворотке, уменьшается по отночению к пленкам, изготовленных на воде, что позволяет рекомендовать молоко и сыворотку как растворитель для изготовления пленок с иелью увеличения их барьерных свойств $и$, как следствие, это позволит увеличить эффективность съедобной пленки как средства сохранения свежести пищевых продуктов.

Ключевые слова: съедобные пленки и покрытия, молоко, сыворотка, поливиниловый спирт, желатин, крахмал картофельный, ИК-спектроскопия, термогравиметрия, термолиз, паропроницаемость.

\title{
Effect of milk and whey on properties of edible films and coatings
}

\author{
O.S. Shulga, A.P. Perepelytsya, S.I. Shulga \\ shulgaos@ukr.net,victanh@ukr.net, shulgasi2015@gmail.com \\ National University of Food Technologies, \\ Vladimirskaya Street, 68, Kyiv, 01601, Ukraine
}

\begin{abstract}
The article presents the results of the study of changes in the properties of edible films made of starch, gelatin, polyvinyl alcohol as film formers, carbamide as a plasticizer, linseed oil - a hydrophobic component and water or milk, or whey as solvents. For the first time, the authors proposed to introduce milk or whey as a solvent into the composition of the edible films and coatings. At present, the literature provides information on the use of milk and whey proteins, and their isolates as film creators. With integrated organoleptic characteristics shown feasibility solvent water replacement for milk and whey, as they do not alter the taste, odor, surface condition, color and transparency of edible films and coatings. In addition, milk and whey increase the nutritional value of edible films and coatings, in particular for components such as protein and calcium. IR studies of the films showed that solvents affect the character, shape of the band of stretching vibrations of the $v O N$-groups of starch. In the IR spectra of water this band more narrow and intense and stored at $3428.57 \mathrm{~cm}^{-1}$, whereas in the milk or whey is broader and less intense. These changes are related to the amount of hydrogen bonds of the hydroxyl group of starch with the components of milk and whey. With the use of polyvinyl alcohol, the band $\mathrm{VON}$ is shifted towards more weak vibrations and is at $3400.56 \mathrm{~cm}^{-1}$, due to the additional hydrogen bonds of polyvinyl alcohol. The thermogravimetric analysis showed that milk and whey contribute to more robust water retention due to hydrogen bonds of their constituents, which increases the temperature of evaporation of moisture and maintains the moisture of the system during the shelf life of the products. The rate of vapor permeability of edible films made on milk and whey decreases with respect to films made on water, which allows the recommendation of milk and whey as a solvent for the production of films in order to increase their barrier properties, and as a result, this will increase the efficiency of the edible film as a means preserving the freshness of food products.
\end{abstract}

Key words: edible films and coatings, milk, whey, polyvinyl alcohol, gelatin, potato starch, IR spectroscopy, thermogravimetry, thermolysis, vapor permeability.

\section{Ветуп}

Під час виготовлення плівок та покриттів способом лиття необхідний розчинник, який далі при висушуванні видаляється. Найбільш поширеними розчинниками для їстівних плівок є вода та етанол.

В літературних джерелах відсутня інформація про ще два можливі розчинники для їстівних плівок молоко та сироватка. Молоко може бути обмежене у використанні через збільшення собівартості виробу, проте сироватка $є$ відходом виробництва, що суттєво збільшувати вартість плівки не буде. Крім того, сироватка, в Україні не використовується в повній мірі, не зважаючи на наукові розробки (Ramos et al., 2016) в цьому напрямі.

У виробництві плівок більшою мірою використовують білок з сироватки (Gennadios, 2002; Onwulata and Huth, 2009; Tomasula, 2009; Ramos, 2011) як ефективний плівкоутворювач, який також має біологічну цінність. Використовують також ізолят білків сироватки для отримання плівки (Zhou et al., 2009; Gounga et al., 2010).
При використанні сироватки необхідно також враховувати їі вплив на здоров'я людини (Solak and Akin, 2012).

Щодо використання молока як розчинника для виготовлення їстівних плівок та покриттів, то в літературі наводяться дані лише 3 використання білків молока та дослідження їх властивостей (Maynes and Krochta, 1994; Avena-Bustillos et al., 1994; Chen, 1995; Tien et al., 2001; Bonnaillie et al., 2014).

Актуальність теми полягає в тому, що запропоновано використати розчинники з більшою харчовою цінністю (молоко або сироватка) для виготовлення істівних плівок і покриттів. Крім того, для сироватки це $\epsilon$ ще одним зі способів ії використання.

Метою дослідження було встановити вплив молока або сироватки на властивості їстівної плівки та покриття.

Для досягнення мети необхідно вирішити наступні завдання:

- виготовити зразки їстівної плівки або покриття;

- $\quad$ визначити комплексний органолептичний показник досліджуваних зразків плівки; 
- визначити наявність хімічних змін за допомогою ІЧ-спектроскопії за різних розчинників;

- визначити вплив розчинників на форми зв'язку вологи у зразках плівки за допомогою термогравіметричного аналізу;

- визначити показник паропроникності досліджуваних зразків плівки.

\section{Матеріал і методи досліджень}

Складові для виробництва плівки наступні: картопляний крохмаль (в/с за ДСТУ 4286:2004, виробник ТОВ «Август-Кий»), желатин (ГОСТ 11293-89, виробник ПрАТ «Екотехніка»), полівініловий спирт (ПВС, E1203, виробник Китай), карбамід (Е927b, виробники Китай), лляна олія (ТУ У 15.4-32448339-001:2005, виробник ТОВ «Агросільпром») та як розчинник використана вода (ДСТУ 7525:2014), молоко (ТУ 15.519492247-025-2004, виробник ПП «Дживальдіс») i сироватка (ДСТУ 4553:2006, виробник ТМ «Вілла Роз»).

\section{Органолептичні показники}

Комплексний показник (Chekmarev, 2010) якості розраховувався згідно з формулою:

$$
K_{o}=M_{1} \frac{P_{1}}{P_{1}^{b}}+M_{2} \frac{P_{2}}{P_{2}^{b}}+M_{3} \frac{P_{3}}{P_{3}^{b}}+M_{4} \frac{P_{4}}{P_{4}^{b}}+M_{5} \frac{P_{5}}{P_{5}^{b}}
$$

де $P_{1}, P_{2}, P_{3}, P_{4}, P_{5}$ - показники, що характеризують органолептичні властивості зразків (смак, колір, запах, поверхня, прозорість);

$P_{1}^{b}, P_{2}^{b}, P_{3}^{b}, P_{4}^{b}, P_{5}^{b}-$ значення основних показників органолептичних властивостей зразків $\left(P_{1}^{b}=P_{2}^{b}=\right.$ $\left.P_{3}^{b}=P_{4}^{b}=P_{5}^{b}=5\right)$;

$M_{1}, M_{2}, M_{3}, M_{4}, M_{5}$ - коефіцієнти вагомості відповідних органолептичних показників плівки $\left(M_{1}+M_{2}+\right.$ $\left.M_{3}+M_{4}+M_{5}=1.0\right)$ : смак $=0,5$; запах $=0,2$; поверхня $=0,1 ;$ колір $=0,1 ;$ прозорість $=0,1$.

IЧ-дослідження проводилося на приладі Nexus 475 фірми Nicolet, Франція.

Термогравіметричне дослідження проводилося відповідно до ГОСТ 29127-91 (Standard Interstate, 1991) на приладі Q-1500B.

Паропроникність визначалася за BS EN 12086:1997 (Standard, A.S.T.M., 1989).

\section{Результати та їх обговорення}

Їстівна плівка або покриття відіграє роль первинного пакування, тому буде визначати органолептичні показники продукту, зокрема зовнішній вигляд, i впливатиме на сприйняття споживачами товару, на поверхню якого буде нанесена. Вплив виду розчинника на органолептичні показники наведено в табл. 1.

Таблиия 1

Значення комплексного органолептичного показника

\begin{tabular}{|c|c|c|c|c|c|c|c|c|c|}
\hline \multirow[b]{2}{*}{ № } & \multicolumn{8}{|c|}{ Вміст компонентів плівки, \% } & \multirow[b]{2}{*}{$\begin{array}{c}\text { Значення комплексного } \\
\text { органолептичного } \\
\text { показника }\end{array}$} \\
\hline & 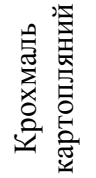 & 声 & U & 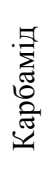 & 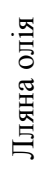 & $\begin{array}{l}\pi \\
\text { T } \\
0 \\
0\end{array}$ & 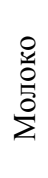 & 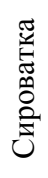 & \\
\hline 1 & 5 & 15 & - & 3 & 5 & 72 & - & - & 1,0 \\
\hline 2 & 5 & 15 & - & 3 & 5 & - & 72 & - & 1,0 \\
\hline 3 & 5 & 15 & - & 3 & 5 & - & - & 72 & 1,0 \\
\hline 4 & 5 & 15 & 1,5 & 3 & 5 & 69 & - & - & 1,0 \\
\hline 5 & 5 & 15 & 1,5 & 3 & 5 & - & 69 & - & 1,0 \\
\hline 6 & 5 & 15 & 1,5 & 3 & 5 & - & - & 69 & 1,0 \\
\hline
\end{tabular}

Отже, згідно з отриманими експериментальними даними вид розчинника не змінює органолептичних властивостей плівки порівняно 3 плівкою, виготовленою на воді, що є важливим, адже молоко і сироватка мають більшу біологічну цінність. Використання молока дозволить збагатити 100 г виробів, на яких буде застосовуватися запропонована їстівна плівка 3 молоком, зокрема на 0,61 г білка та 26,4 мг\% Ca (Skurikhin and Tutelyan, 2002). При використанні молочної сироватки харчова цінність виробів з їстівною плівкою збільшиться на 0,21 г білка та 13,2 мг\% Са.

3 метою встановлення якісних хімічних змін, що відбуваються або не відбуваються в плівці під час іiі виготовлення при зміні розчинника були отримані ІЧспектри для шести плівок. Склади плівок наведено в табл. 1.

В ІЧ-спектрі зразка плівки №1 з розчинником вода (рис. 1a) наявна інтенсивна смуга при $3428,57 \mathrm{~cm}^{-1}$, яка відповідає валентним коливанням $\mathrm{\vee OH}$ i $v \mathrm{NH}$.
Відомо (Silverstein et al., 2011), що положення і характер смуги залежить від ступеня участі гідроксильної групи у водневих зв'язках. Гідроксильна група, яка бере участь у міжмолекулярному водневому зв'язку характеризується широким інтенсивним максимумом поглинання в області 3200-3600 $\mathrm{cm}^{-1}$. У спектрі (рис. 1a) є широка смуга поглинання при $3428,57 \mathrm{~cm}^{-1}$. Смуга 3014,00 $\mathrm{cm}^{-1}$, що належить амонійній групі желатину за наявності лляної олії. Інтенсивна смуга 2924,36 $\mathrm{cm}^{-1}$ і менш інтенсивна смуга $2857,14 \mathrm{~cm}^{-1}$ обумовлені наявністю асиметричних $\mathrm{i}$ симетричних валентних коливань $v \mathrm{C}-\mathrm{H}$, що знаходяться у залишках глюкопіранозних кілець крохмалю.

Інтенсивна смуга поглинання 1745,45 $\mathrm{cm}^{-1}$ відноситься до валентних коливань карбонільної групи лляної олії та карбонільної групи, що входить до складу желатину. Валентні коливання карбонільної групи незалежно від того в яку функціональну групу входить, проявляються високо інтенсивним максиму- 
мом в області 1650-1850 $\mathrm{cm}^{-1}$ (Mironov and Yankovskiy, 1985), де інші смуги практично відсутні. Коливання $v \mathrm{C}=\mathrm{O} \epsilon$ найбільш характеристичними $\mathrm{i}$ дозволяють переконливо довести наявність або відсутність карбонільної групи в речовині. Смуга середньої інтенсивності 1454,54 $\mathrm{cm}^{-1}$ - це деформаційні коливання метиленових $\left(\delta \mathrm{CH}_{2}\right)$ i метинових $(\delta \mathrm{CH})$ груп глюкопіранозних кілець. Смуга поглинання середньої інтенсивності 1630,76 $\mathrm{cm}^{-1}$ належить деформаційним коливанням адсорбційно зв'язаної води.

Смуга середньої інтенсивності $1160,83 \mathrm{~cm}^{-1}$ характерна для деформаційних коливань $\delta(\mathrm{OH})+\left(\delta \mathrm{CH}_{2}\right)$.

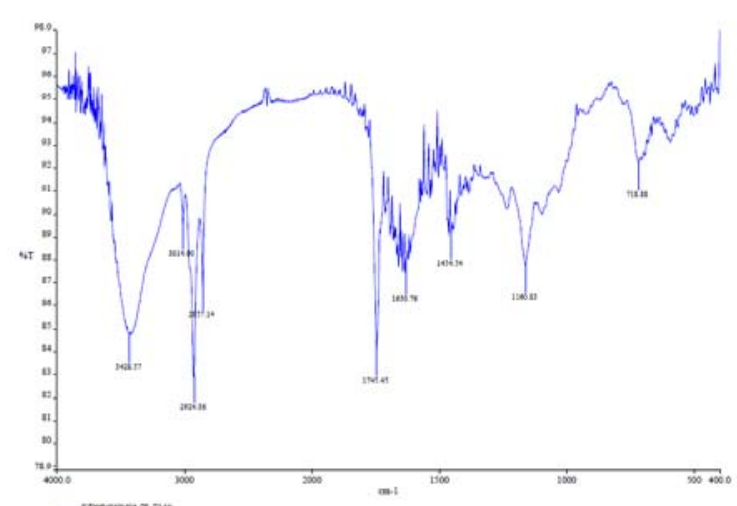

a

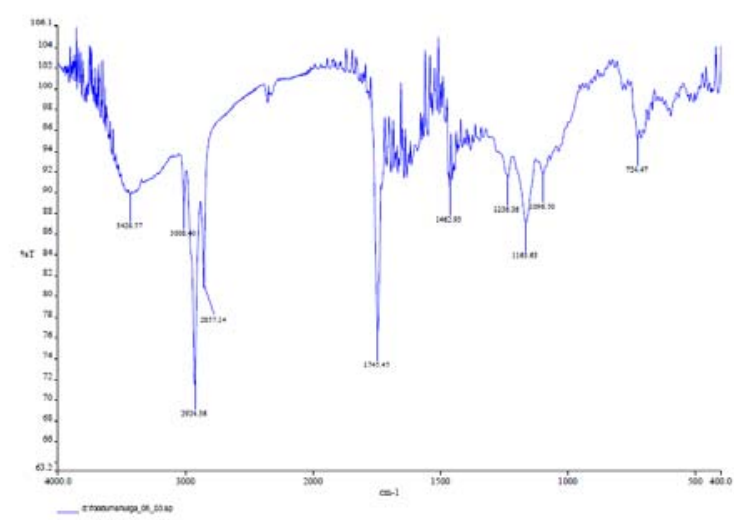

B

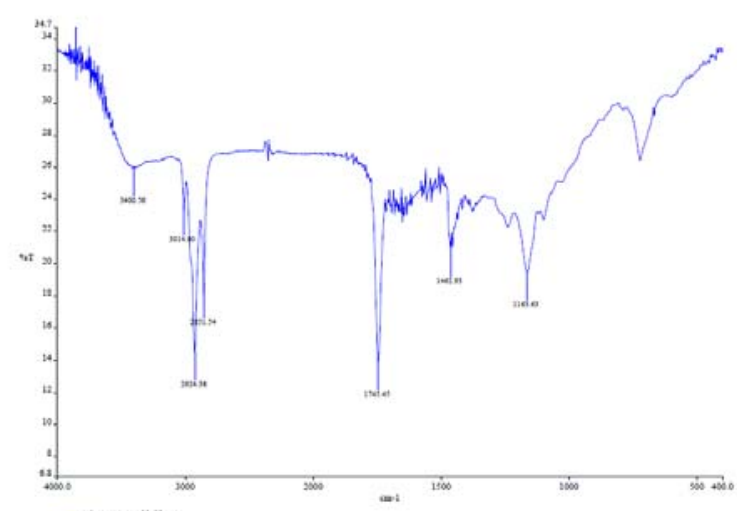

Д
Смуга слабої інтенсивності 1091,50 $\mathrm{cm}^{-1}-$ це $v_{\mathrm{a}}(\mathrm{C}-\mathrm{O}-$ C) містка, смуга слабкої інтенсивності 718,88 $\mathrm{cm}^{-1}$ коливання кільця (Workman and Weyer, 2012). Смуга слабкої інтенсивності 598,60 $\mathrm{cm}^{-1}$ та інші згідно з літературними джерелами (Silverstein et al., 2011), що в цій області відбувається скелетні коливання С-C зв'язків або поглинання піранозного кільця.

При порівнянні ІЧ-спектру плівки №1 зразка з розчинником вода (рис. 1а) зі ІЧ-спектром плівки № 23 розчинником молоко (рис. 1б) чітко видно різницю смуг валентних коливань -OH i -NH як за характером, так і за інтенсивністю.

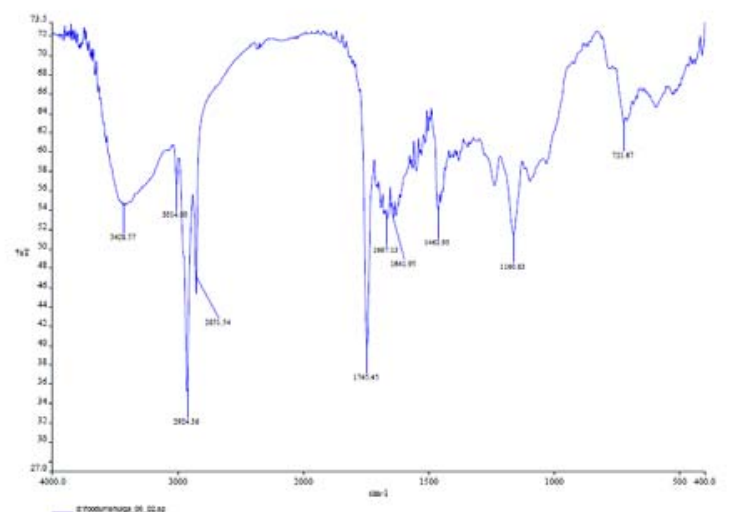

6

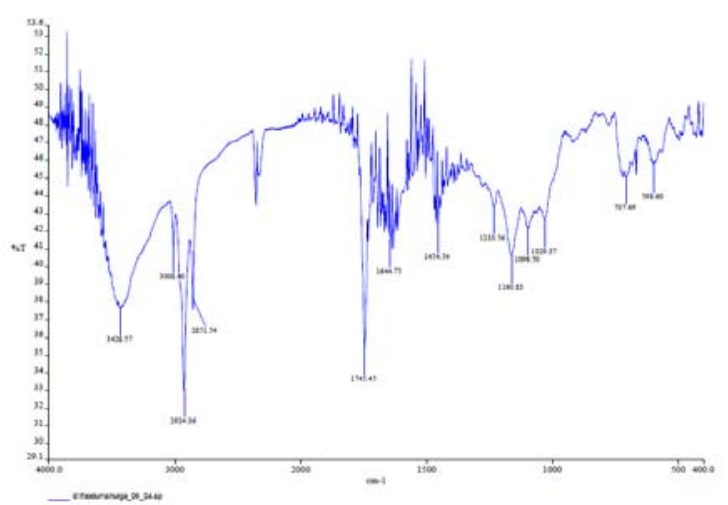

$\Gamma$

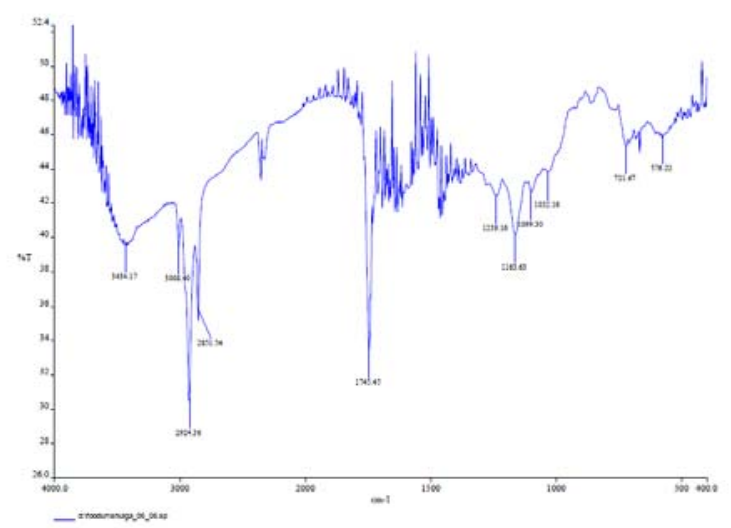

e
Максимуми цих смуг коливання однакові 3428,57 $\mathrm{cm}^{-1}$, але смуга спектру плівки № 1 на воді вужча та значно інтенсивніша порівняно 3 плівкою № 2 на молоці. Відомо (Mironov and Yankovskiy, 1985), що положення і характер смуги валентних коливань vOH залежить від ступеня участі гідроксильної групи у водневому зв'язку. 
Водневий зв' язок змінює силову константу зв'язку О-Н і призводить до зменшення частоти коливань і характеру смуги поглинання. Таким чином, складові молока (білок, вуглеводи) впливають на участь гідроксильних груп крохмалю і желатину в утворення водневих зв'язків, що в свою чергу впливає на міцність плівки.

При порівнянні ІЧ-спектру плівки № 1 на воді (рис. 1а) з ІЧ-спектром плівки № 3, виготовленої на сироватці (рис. 1в), видно різницю смуг валентних коливань -ОН i -NH, аналогічну до попереднього порівняння. Зазначена закономірність була очікувана, оскільки в сироватку переходить водорозчинний білок молока та вуглеводи.

При порівнянні ІЧ-спектрів плівок № 4 (на воді, рис. 1г), № 5 (на молоці, рис. 1д), №6 (на сироватці, рис. 1е) видно, що максимуми смуг валентних коливань vОН груп лежать при 3428,57 $\mathrm{cm}^{-1}$ - плівка № 4, $3400,56 \mathrm{~cm}^{-1}$ - плівка №5 та 3434,17 $\mathrm{cm}^{-1}$, що пояснюється наявністю у складах плівки ПВС, який сприяє збільшенню кількості утворення водневих зв'язків, що і визначає характер валентних коливань ОН-груп. Порівнюючи спектри плівок № 1 (рис. 1а) та 4 (рис. 1г) чітко видно, що смуга валентних коливань плівки № 1 більш інтенсивна і менш широка, що підтверджує наявність меншої кількості водневих зв'язків, оскільки до складу плівки не входить ПВС. В ІЧ-спектрі плівки № 5 (рис. 1д) смуга валентних коливань ОН-групи дуже слабка і широка та лежить в області більш низьких коливань (3400,56 $\left.\mathrm{cm}^{-1}\right)$, що вказує на високий рівень утворення водневих зв'язків в плівці № 5, де наявний ПВС та складові молока (жир, білок, вуглеводи), а також більший вміст крохмалю згідно до рецептури плівки (див. табл. 1).

Отже, на основі проведеного ІЧ-дослідження можна зазначити, що розчинники впливають на валентні коливання vОН-груп крохмалю змінюючи форму, характер та область знаходження їх коливань.

\section{Термогравіметричне дослідження}

У таблиці 2 наведено результати аналізу дериватограм для досліджуваних зразків плівки з різними розчинниками, склади плівок наведено в табл. 1. Аналізуючи результати табл. 2, випливає закономірність, що найменша кількість адсорбованої води виділяється у зразках виготовлених на молоці (№ 2 та 5) - 2,5\% та $1,2 \%$ відповідно, що пояснюється утворенням більшої кількості водневих зв'язків складовими молока (білком та лактозою) i, як наслідок, вода утримується сильніше, що не дозволяє їй вільно відокремлюватися за відносно низьких температур I зони термолізу (20$\left.100{ }^{\circ} \mathrm{C}\right)$.

Зони термолізу зразків плівки з різними видами розчинників

Таблиия 2

\begin{tabular}{|c|c|c|c|c|c|c|c|c|c|c|}
\hline \multirow{4}{*}{ № } & \multicolumn{10}{|c|}{ Зони термолізу } \\
\hline & \multirow{2}{*}{\multicolumn{2}{|c|}{$\begin{array}{c}\text { I } \\
\text { Виділення } \\
\text { адсорбованої } \\
\text { води } \\
\end{array}$}} & \multirow{2}{*}{\multicolumn{2}{|c|}{$\begin{array}{c}\text { II } \\
\text { Виділення кристалі- } \\
\text { заційної води }\end{array}$}} & \multicolumn{4}{|c|}{ III } & \multirow{2}{*}{\multicolumn{2}{|c|}{ IV }} \\
\hline & & & & & \multicolumn{2}{|c|}{$\begin{array}{c}\text { Термоліз безводних } \\
\text { продуктів }\end{array}$} & \multicolumn{2}{|c|}{ Обвуглення } & & \\
\hline & $\begin{array}{l}\text { Темпе- } \\
\text { ратур- } \\
\text { ний } \\
\text { інтер- } \\
\text { вал, }{ }^{\circ} \mathrm{C} \\
\end{array}$ & $\underset{\%}{\Delta \mathrm{m},}$ & $\begin{array}{c}\text { Температур- } \\
\text { ний інтервал, } \\
{ }^{\circ} \mathrm{C}\end{array}$ & $\underset{\%}{\Delta \mathrm{m},}$ & $\begin{array}{c}\text { Темпера- } \\
\text { турний } \\
\text { інтервал, } \\
{ }^{\circ} \mathrm{C}\end{array}$ & $\Delta \mathrm{m}, \%$ & $\begin{array}{l}\text { Темпера- } \\
\text { турний } \\
\text { інтервал, } \\
{ }^{\circ} \mathrm{C}\end{array}$ & $\Delta \mathrm{m}, \%$ & $\begin{array}{l}\text { Температурний } \\
\text { інтервал, }{ }^{\circ} \mathrm{C}\end{array}$ & $\Delta \mathrm{m}, \%$ \\
\hline 1 & $20-100$ & 5,0 & $\begin{array}{l}100-160 \\
160-200^{3}\end{array}$ & $\begin{array}{l}6,2 \\
2,0\end{array}$ & $\begin{array}{l}200-300 \\
300-350\end{array}$ & $\begin{array}{l}11,2 \\
17,6\end{array}$ & $\begin{array}{l}350-400 \\
400-420 \\
420-520\end{array}$ & $\begin{array}{l}10,0 \\
6,2 \\
14,1\end{array}$ & $\begin{array}{l}520-560^{1} \\
560-700^{1} \\
700-730^{1} \\
730-820^{1} \\
820-900^{2}\end{array}$ & $\begin{array}{l}3,5 \\
14,1 \\
1,2 \\
6,9 \\
1,2 \\
\end{array}$ \\
\hline 2 & $20-100$ & 2,5 & $\begin{array}{l}100-170 \\
170-220^{3}\end{array}$ & $\begin{array}{l}6,2 \\
2,5\end{array}$ & $\begin{array}{l}220-250 \\
250-310 \\
310-380 \\
\end{array}$ & $\begin{array}{l}3,7 \\
4,4 \\
21,4 \\
\end{array}$ & $\begin{array}{l}380-420 \\
420-450 \\
450-570 \\
\end{array}$ & $\begin{array}{l}6,2 \\
8,9 \\
11,5 \\
\end{array}$ & $\begin{array}{l}570-750^{1} \\
750-900^{2}\end{array}$ & $\begin{array}{l}26,4 \\
1,2\end{array}$ \\
\hline 3 & $20-100$ & 3,7 & $100-200^{3}$ & 8,7 & $\begin{array}{l}200-230 \\
230-300 \\
300-360 \\
\end{array}$ & $\begin{array}{l}3,7 \\
5,0 \\
20,8 \\
\end{array}$ & $\begin{array}{l}360-410 \\
410-430 \\
430-500\end{array}$ & $\begin{array}{l}7,5 \\
6,2 \\
10,0 \\
\end{array}$ & $\begin{array}{l}500-550^{1} \\
550-720^{1} \\
720-900^{2}\end{array}$ & $\begin{array}{l}3,7 \\
25,7 \\
2,5 \\
\end{array}$ \\
\hline 4 & $20-100$ & 2,5 & $\begin{array}{l}100-170 \\
170-210^{3}\end{array}$ & $\begin{array}{l}5,0 \\
1,2\end{array}$ & $\begin{array}{l}210-300 \\
300-360\end{array}$ & $\begin{array}{l}7,6 \\
22,9\end{array}$ & $\begin{array}{l}360-420 \\
420-520\end{array}$ & $\begin{array}{l}10,2 \\
17,8\end{array}$ & $\begin{array}{l}520-560^{1} \\
560-720^{1} \\
720-840^{1} \\
840-900^{2}\end{array}$ & $\begin{array}{l}1,2 \\
20,4 \\
5,0 \\
1,2\end{array}$ \\
\hline 5 & $20-100$ & 1,2 & $\begin{array}{l}100-130 \\
130-200^{3}\end{array}$ & $\begin{array}{l}1,8 \\
4,1\end{array}$ & $\begin{array}{l}200-250 \\
250-300 \\
300-360 \\
\end{array}$ & $\begin{array}{l}7,1 \\
4,7 \\
17,6 \\
\end{array}$ & $\begin{array}{l}360-410 \\
410-430 \\
430-500\end{array}$ & $\begin{array}{l}10,6 \\
8,8 \\
8,8 \\
\end{array}$ & $\begin{array}{l}500-540^{1} \\
540-720^{1} \\
720-900^{2}\end{array}$ & $\begin{array}{l}5,9 \\
22,3 \\
1,8 \\
\end{array}$ \\
\hline 6 & $20-100$ & 2,3 & $\begin{array}{l}100-150 \\
150-210^{3}\end{array}$ & $\begin{array}{l}7,1 \\
1,8\end{array}$ & $\begin{array}{l}210-300 \\
300-360\end{array}$ & $\begin{array}{l}8,2 \\
18,8\end{array}$ & $\begin{array}{l}360-410 \\
410-430 \\
430-500 \\
\end{array}$ & $\begin{array}{l}8,9 \\
11,8 \\
8,9 \\
\end{array}$ & $\begin{array}{l}500-550^{1} \\
550-720^{1} \\
720-900^{2} \\
\end{array}$ & $\begin{array}{l}4,1 \\
24,3 \\
1,2\end{array}$ \\
\hline
\end{tabular}

Примітки: 1. Горіння продуктів обвуглення; 2. Термічне розкладання продуктів повного горіння;

3. В цьому інтервалі за нижчих температур виділяється кристалізаційна вода, а при вищих в області близьких до $200{ }^{\circ} \mathrm{C}$ відбувається термоліз.

Крім того, плівки, до складу яких входить ПВС (зразки № 4-6) кількість адсорбованої води (зона I) відокремлюється менше 1,2-2,5\% порівняно зі зраз-

ками, які не містіть ПВС (№ 1-3) зменшення маси становить 2,5-5,0\%. Це можна пояснити тим, що за 
наявності ПВС у плівці утворюється більша кількість водневих зв'язків, які ще міцніше утримують воду.

Вище $100{ }^{\circ} \mathrm{C}$ і до $130-150{ }^{\circ} \mathrm{C}$, а також в області $150-170{ }^{\circ} \mathrm{C}-200-220{ }^{\circ} \mathrm{C}$ процес втрати маси пояснюється відокремленням кристалізаційної води, яка має однакову хімічну природу, тому зміна маси в зоні II відбувається приблизно рівномірно і знаходиться в межах 5,9-8,9\%. При цьому ці інтервали для окремих зразків не розділяються. В III зоні термолізу вище 200-220 ${ }^{\circ} \mathrm{C}$ всі зразки зазнають глибокого розкладу i зменшення маси зразків відбувається рівномірно незалежно від використаного розчинника (27,0-30,5\%). В III зоні обвуглення за температури $360-500{ }^{\circ} \mathrm{C}$ відбувається горіння, проте не повне, оскільки зразок обвуглюється і зменшення маси також відбувається в діапазоні 23,7-30,3\%. Отримані результати узгоджуються 3 літературними даними щодо дослідження термолізу їстівних та біодеградабельних плівок виготовлених з білків молока та желатину (Barreto et al., 2003), соєвого білкового ізоляту-натрію додецилсульфату (Schmidt et al., 2005) та ксантану з різними видами крохмалю (Soares et al., 2005).

В IV зоні після $500-520{ }^{\circ} \mathrm{C}$ і до $720-840{ }^{\circ} \mathrm{C}$ обвуглені продукти горять, оскільки відбувається швидке зниження маси зразків. Після 720-840 ${ }^{\circ} \mathrm{C}$ втрата маси зразків досить мала - 1,2-2,5\% і викликана термічним розкладом продуктів горіння, що мають неорганічну

природу. В цій зоні термолізу для зразків № 1 та 4 присутня зона $730-820{ }^{\circ} \mathrm{C}$ та $720-840{ }^{\circ} \mathrm{C}$ відповідно, якої немає для зразків виготовлених на молоці та сироватці (№ 2, 3, 5 та 6). Наявність цієї зони пояснюється ймовірним утворенням комплексів іонів мінеральних речовин води з желатином плівки, що не відбувається у зразках з молоком та сироваткою, оскільки в цих розчинниках мінеральні речовини вже знаходяться у зв'язаному стані білковими речовинами молока та сироватки. Крім того, в IV зоні за температури $540{ }^{\circ} \mathrm{C}$ (Nikolsky, 1964) відбувається розкладання неорганічної солі $\mathrm{MgCO}_{3}$, що також спричиняє зменшення маси зразка.

Отже, молоко та сироватка як розчинники для виготовлення плівки сприяють більш міцному утриманню води за рахунок водневих зв'язків складових молока та сироватки, що збільшує температуру випаровування вологи.

\section{Паропроникність}

Паропроникність - показник, який в значній мірі визначає здатність плівки та покриття утримувати вологу та зберігати свіжість виробів, що вкрай важливо для хлібобулочних та кондитерських виробів, в яких термін зберігання визначається швидкістю десорбційних процесів - мармеладні та пряникові вироби, а також помадні цукерки. Отримані експериментальні результати наведені в табл. 3.

Табличя 3

Значення показника паропроникності досліджуваних зразків плівки

\begin{tabular}{|c|c|c|c|c|c|c|c|c|c|}
\hline \multirow[b]{2}{*}{ № } & \multicolumn{8}{|c|}{ Вміст компонентів, \% } & \multirow[b]{2}{*}{$\begin{array}{c}\text { Паропроникність, } \\
\text { мг/м·год. } \text { КПа }\end{array}$} \\
\hline & 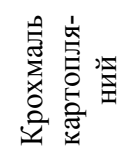 & 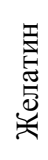 & 荨 & 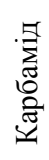 & 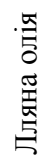 & 采 & \begin{tabular}{l}
0 \\
on \\
0 \\
$\vdots$ \\
\multirow{2}{0}{}
\end{tabular} & 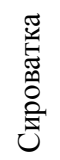 & \\
\hline 1 & 5 & 15 & - & 3 & 5 & 72 & - & - & $6,01 \pm 0,2$ \\
\hline 2 & 5 & 15 & - & 3 & 5 & - & 72 & - & $5,05 \pm 0,4$ \\
\hline 3 & 5 & 15 & - & 3 & 5 & - & - & 72 & $5,84 \pm 0,3$ \\
\hline 4 & 5 & 15 & 1,5 & 3 & 5 & 69 & - & - & $7,64 \pm 03$ \\
\hline 5 & 5 & 15 & 1,5 & 3 & 5 & - & 69 & - & $6,85 \pm 0,1$ \\
\hline 6 & 5 & 15 & 1,5 & 3 & 5 & - & - & 69 & $7,11 \pm 0,2$ \\
\hline
\end{tabular}

Результати табл. 3 показують, що молоко сприяє зменшенню показника паропроникності, оскільки складові молока утворюють додаткові водневі зв'язки 3 плівко утворювачами - крохмаль та желатин, що сприяє зміцненню матриці плівки.

В літературі наводяться дані, що для плівок виготовлених 3 ізолятів білків молока як плівкоутворювачів варто застосовувати етилмалеімід або цистеїн для зменшення показника паропроникності (Folegatti et al., 1998), а для плівок з соєвого ізоляту додецил сульфат натрію (Mei and Zhao, 2003).

Дані таблиці 3 також вказують на те, що наявність у складі плівки ПВС сприяє незначному збільшенню показника паропроникності, що можна пояснити тим, що ПВС, як зазначалося вище, сприяє утворенню додаткових водневих зв'язків 3 водою, що в свою чергу зменшує цілісність матриці плівки і створює пори для проникнення парів води. Крохмаль та желатин як плівкоутворювачі руйнують цілісність матриці
ПВС, що також сприяє збільшенню показника паропроникності відносно плівок, до складу яких ПВС не входить (зразки № 4-6).

\section{Висновки}

Встановлена доцільність застосування молока та сироватки за допомогою розрахованого комплексного органолептичного показника плівки. Використання молока дозволить збагатити 100 г виробів, на яких буде застосовуватися запропонована їстівна плівка 3 молоком, зокрема на 0,61 г білка та 26,4 мг\% Са. При використанні молочної сироватки харчова цінність виробів з їстівною плівкою збільшиться на 0.21 г білка та 13,2 мг\% Са. ІЧ-дослідження плівок показало, що розчинники впливають на валентні коливання vOН-груп крохмалю змінюючи форму, характер та область знаходження їх коливань. Термогравіметричний аналіз показав, що молоко та сироватка сприяють 
збільшенню температури випаровування вологи. Визначений показник паропроникності вказує, що молоко і сироватка сприяють збільшенню бар'єрних властивостей їстівної плівки i, як наслідок, збільшують ефективність іiі для зберігання свіжості харчових продуктів.

Перспективи подальших досліджень полягають у розширенні спектру досліджуваних показників, наприклад за рахунок фізико-механічних показників. Крім того, запропоновані розчинники варто спробувати і для інших складів плівки.

\section{Бібліографічні посилання}

Ramos, O.L., Pereira, R.N., Rodrigues, R.M., Teixeira, J.A., Vicente, A.A., Malcata, F.X. (2016). Whey and whey powders: production and uses. Encyclopedia of Food and Health, 498-505.

Onwulata, C., Huth, P. (Eds.). (2009). Whey processing, functionality and health benefits (Vol. 82). John Wiley \& Sons.

Gennadios, A. (2002). Protein-based films and coatings. CRC Press.

Ramos, Ó.L.D.S. (2011). Development and characterization of bioactive, edible whey protein films and coatings to improve quality and safety of food products.

Tomasula, P.M. (2009). Using dairy ingredients to produce edible films and biodegradable packaging materials. Dairy-derived ingredients: food and nutraceutical uses, 589-624.

Gounga, M.E., XU, S.Y., Wang, Z. (2010). Film forming mechanism and mechanical and thermal properties of whey protein isolate-based edible films as affected by protein concentration, glycerol ratio and pullulan content. Journal of food biochemistry, 34(3), 501-519.

Zhou, J.J., Wang, S.Y., Gunasekaran, S. (2009). Preparation and characterization of whey protein film incorporated with $\mathrm{TiO}_{2}$ nanoparticles. Journal of food science, 74(7), 50-56.

Solak, B.B., Akin, N. (2012). Health benefits of whey protein: a review. Journal of Food Science and Engineering, 2(3), 129.

Bonnaillie, L.M., Zhang, H., Akkurt, S., Yam, K. L., Tomasula, P.M. (2014). Casein films: The effects of formulation, environmental conditions and the addition of citric pectin on the structure and mechanical properties. Polymers, 6(7), 2018-2036.

Maynes, J.R., Krochta, J.M. (1994). Properties of edible films from total milk protein. Journal of food science, 59(4), 909-911.

Chen, H. (1995). Functional properties and applications of edible films made of milk proteins. Journal of dairy science, 78(11), 2563-2583.

Avena-Bustillos, R.J., Cisneros-Zevallos, L.A., Krochta, J.M., Saltveit, M.E. (1994). Application of caseinlipid edible film emulsions to reduce white blush on minimally processed carrots. Postharvest Biology and Technology, 4(4), 319-329.

Tien, C., Vachon, C., Mateescu, M.A., Lacroix, M. (2001). Milk protein coatings prevent oxidative browning of apples and potatoes. Journal of food science, 66(4), 512-516.

Chekmarev, A.N. (2010). Qualimetry and quality management. Part 1. Samara, Russia: Izd-vo Samar. gos. aerokosm. un-ta (in Russian).

Standard Interstate (1991). Plastics. Thermogravimetric analysis of polymers. Temperature scanning method. (GSS 29127-91). Moscow: IPK «Izd-vo standartov» (in Russian).

Standard, A.S.T.M. (1989). Standard test methods for water vapor transmission of materials. Annual book of ASTM standards. Designation E96-E80, 730-739.

Skurikhin, I.M., Tutelyan, V.A. (2002). Chemical composition of Russian food products. Moscow, Russia: DeLi print (in Russian).

Silverstein, R., Webster, F., Kiml, D. (2011). Spectrometric identification of organic compounds. Moscow, Russia: BINOM (in Russian).

Mironov, V.A., Yankovskiy, S.A. (1985). Spectroscopy in Organic Chemistry. Collection of problems. Moscow, Russia: Himija (in Russian).

Workman Jr.J., Weyer, L. (2012). Practical guide and spectral atlas for interpretive near-infrared spectroscopy. CRC Press.

Barreto, P.L.M., Pires, A.T.N., Soldi, V. (2003). Thermal degradation of edible films based on milk proteins and gelatin in inert atmosphere. Polymer Degradation and Stability, 79(1), 147-152.

Schmidt, V., Giacomelli, C., Soldi, V. (2005). Thermal stability of films formed by soy protein isolate-sodium dodecyl sulfate. Polymer Degradation and Stability, 87(1), 25-31.

Soares, R.M.D., Lima, A.M.F., Oliveira, R.V.B., Pires, A.T.N., Soldi, V. (2005). Thermal degradation of biodegradable edible films based on xanthan and starches from different sources. Polymer degradation and stability, 90(3), 449-454.

Nikolsky, B.P. (1964). Reference book of the chemist. Vol. 2. The main properties of inorganic and organic compounds. St.Petersburg, Russia: Leningradskoe otdelenie izdatel'stva «Himija» (in Russian).

Folegatti, M.I., Antunes, A.J., Marcondes, J.A. (1998). Mechanical and permeability properties of milk protein films. Brazilian Archives of Biology and Technology, 41(3). Retrieved from http://dx.doi.org/10.1590/S1516-89131998000300008

Mei, Y., Zhao, Y. (2003). Barrier and mechanical properties of milk protein-based edible films containing nutraceuticals. Journal of agricultural and food chemistry, 51(7), 1914-1918. 